\title{
The synstigma turns the fig into a large flower
}

Simone P. Teixeira ${ }^{1, *}$, Marina F. B. Costa ${ }^{1,2}$, João Paulo Basso-Alves ${ }^{2,3}$, Finn Kjellberg ${ }^{4}$ And Rodrigo A. S. Pereira ${ }^{5}$

${ }^{1}$ Faculdade de Ciências Farmacêuticas de Ribeirão Preto, Universidade de São Paulo, Av. do Café, s/n, 14040-903, Ribeirão Preto, SP, Brazil

${ }^{2}$ PPG em Biologia Vegetal, Instituto de Biologia, Universidade Estadual de Campinas, Caixa Postal 6109, 13083-970, Campinas, SP, Brazil

${ }^{3}$ Instituto de Pesquisa do Jardim Botânico do Rio de Janeiro, DIPEQ, Rua Pacheco Leão, 915, 22460030, Rio de Janeiro, RJ, Brazil

${ }^{4}$ CEFE UMR 5175, CNRS-Université de Montpellier, Université Paul-Valéry Montpellier, EPHE, 1919 route de Mende, F-34293 Montpellier Cédex 5, France

${ }^{5}$ Faculdade de Filosofia, Ciências e Letras de Ribeirão Preto, Universidade de São Paulo, Av. Bandeirantes 3900, 14040-903, Ribeirão Preto, SP, Brazil

*Corresponding author. E-mail: spadua@fcfrp.usp.br

\section{Abstract}

The synstigma is a structure formed by clusters of two to several stigmas, whether in the same or between different flowers. Although rare in angiosperms, synstigmas are found in $c .500$ out of the $c$. 750 Ficus spp. (Moraceae). This floral structure is associated with fig-fig wasp pollinating mutualism. The synstigma structure and pollen tube pathways were studied in six Ficus spp. from Ficus section Americanae to test the hypothesis that the synstigma allows pollen grains deposited on a stigma to emit pollen tubes that can grow laterally and fertilize surrounding flowers. Syconia containing recently pollinated stigmas were collected and dissected, and the stigmas were processed for analyses with light and scanning and transmission electron microscopy. The arrangement of the synstigmas across species can be spaced or congested, with the number of stigmas per synstigma ranging from two to 20. Contact between the stigmas in a synstigma occurs by the intertwining of the stigmatic branches and papillae; their union is firm or loose. The pollen tube grows through live cells of the transmitting tissue until reaching the ovule micropyle. Curved pollen tubes growing from one stigma to another were observed in five out of the six species studied. The curvilinear morphology of pollen tubes probably results from 
competition by pollen between the stigmas composing a synstigma via chemotropic signals. The synstigma appears to be a key adaptation that ensures seed production by flowers not exploited by the fig wasps in actively pollinated Ficus spp.

Additional keywords: active pollination - Ficus - Moraceae - pollen grain - pollen-pistil interaction - pollen tube - ultrastructure.

\section{Introduction}

A synstigma is a rarely reported structure of angiosperms formed by the clustering of two or more stigmas originating from a single flower or from different flowers. Records of synstigmas have been reported in: early-diverging angiosperms (Amborellaceae, Austrobaileyaceae, Illiciaceae, Nymphaeaceae, Schisandraceae) and magnoliids (Annonaceae, Calycanthaceae, Monimiaceae, Siparunaceae), in which the gynoecium is apocarpic, but contacted by an extragynoecial compitum (Endress, 2011; Endress \& Doyle, 2015); Rosa setigera Michx. (Rosaceae), in which the apocarpic gynoecium is contacted by an intrastylar compitum (Kemp, Kevan \& Posluszny, 1993); for two species of Procris Comm. ex Juss. (Urticaceae) in which the congested arrangement of the pistillate inflorescence could promote the union of surrounding stigmas for the shared reception of pollen grains (Weberling, 1989); and, apparently, for Typhaceae, in which there is a union of groups of four flowers (Carvalho \& Mariath, 2019) and pollen dispersed in tetrads (Nicholls \& Cook, 1986).

The clade with the largest number of records so far is Ficus L. (Moraceae), with 500 species predicted to form synstigmas (Verkerke, 1989; Jousselin, Rasplus \& Kjellberg, 2003b; Jousselin \& Kjellberg, 2001; BassoAlves et al., 2014; Teixeira et al., 2018). A synstigma can be a continuous structure inside a syconium (the urn-shaped inflorescence of Ficus, the fig), composed of all stigmas of all flowers (Galil \& Eisikowitch, 1968) or the result of contact between two or more stigmas of distinct flowers, acting as a common surface for pollen germination (Jousselin \& Kjellberg, 2001; Jousselin Kjellberg \& Herre, 2004, 2003a,).

Ficus is taxonomically and ecologically diverse (Bruun-Lund et al., 2018; Clement et al., 2020), encompassing c. 750 of the 1100 species described for the family (Berg, 2005). This high level of diversity seems to result from the obligatory mutualistic interaction established with small Agaonidae wasps ( Kjellberg et al., 2005). However, the fig tree and the fig wasp have divergent reproductive interests. The reward for the pollinating wasp is the oviposition site (i.e. flower ovaries) to rear its brood. Fertilized flowers are assumed to be better quality food for the wasp larvae than unfertilized ones, creating a selective pressure from the wasp side for the evolution of active pollination, i.e. the 
pollinating fig wasp actively collects pollen in its natal fig, stores it in specialized thoracic structures called 'pollen pockets' and later actively deposits it on stigmas of the flowers into which they oviposit (Jousselin \& Kjellberg, 2001).

The active pollination in Ficus could have a high cost for plants on seed set if wasps only pollinate the flower into which they oviposit. This effect may generate a selective pressure from the plant side for the development of the synstigma, which could then be interpreted as an adaptation to guarantee seed production in some of the fig flowers. As such, active pollination should be seen coevolving with other features, such as the spatial arrangement of the flowers within the syconium. In passively pollinated species (those in which pollinating wasps have no behaviour of collecting/depositing pollen), the synstigma is not present and the flowers that receive the wasp eggs and the seed-producing flowers are morphologically different, especially regarding the length of the stigmas. The longer-styled flowers have long filiform stigmatic branches projecting into the fig cavity that brush the body of the wasp and collect pollen in the process, whereas the shorter-styled flowers have short filiform stigmatic branches stigmas that do not receive pollen (Jousselin et al., 2003a, 2004; Teixeira et al., 2018).

There is a strong correlation between the presence of synstigma and active pollination in both monoecious and gynodioecious species of Ficus (Jousselin et al., 2003b). In monoecious Ficus spp., the flowers are arranged in several layers so that some ovaries are closer to the inner wall of the syconium and other ovaries are closer to the central cavity of the syconium. The length of the styles varies accordingly so that the stigmas may unite at the same level, forming a synstigma. Both active and passive pollinating wasps oviposit shorter-styled flowers, probably because these flowers are more suitable for the offspring development (Anstett, 2001) and less exposed to parasites (Al-Beidh et al., 2012). Longer-styled flowers generally do not receive wasp eggs and may produce a seed if their embryo sac is fertilized (Jousselin \& Kjellberg, 2001).

The hypothetical function of the synstigma in Ficus spp. is to allow pollen grains deposited on the stigma of a flower to emit pollen tubes that will grow laterally through nearby stigmas and fertilize non-pollinated neighbouring flowers, thus promoting seed production (Jousselin \& Kjellberg, 2001). Despite the paradigm of the functional significance of the synstigma for mutualism, there are no detailed studies of the morphological structure or its functional significance in relation to pollen germination.

In this study, we aimed to test the hypothesis that the synstigma allows pollen grains deposited on a stigma to emit pollen tubes that can grow laterally and fertilize surrounding flowers, favouring the 
production of seeds and thus balancing the costs and benefits of the fig-fig wasp mutualism. To that end, the detailed structure of the synstigma and the pollen tube pathways were studied in six monoecious, actively pollinated species of Ficus section Americanae Miq.

\section{Material and methods}

Six species of Ficus subgenus Urostigma (Gasp.) Miq. section Americanae were selected for this study (Table 1), and at least two individuals from each species were sampled. The species were chosen to cover a range of syconium sizes to allow the exploration of one possible source of variation associated with syconium size that can impose physical constraints on stigma arrangement and affect pollen grains/pistillate flowers ratio.

At least six syconia were collected from each species at the stage when the pistillate flowers presented receptive stigmas. To follow the entire course of the pollen tube through the pistil, figs were collected at three successive stages: (1) syconium containing live pollinating wasps; (2) syconium containing dead wasps and clear and turgid stigmas and (3) syconium containing dead wasps and decaying brownish stigmas.

The syconia were cut in half and fixed in FAA 50 (Johansen, 1940), FNT (Lillie, 1954) or Karnovsky solution (Karnovsky, 1965). The total number of flowers per syconium was estimated by counting flowers in one syconium of each species. The structure of the synstigma was described by observing the samples using stereoscopic, scanning electron microscopy (SEM, surface examination) and light microscopy (LM, anatomical examination). For the surface examination, small portions of syconia were dehydrated in an ethanolic series, critical point dried in a Bal-Tec CPD 030 apparatus, mounted on a metallic support on carbon tape and/or adhesive glue and sputtered with gold in a Bal-Tec SCD 050 apparatus. Observations were performed using Jeol JSM 5200 and Jeol JSM6610LV SEM at 25 $\mathrm{kV}$.

For the anatomical examination, small portions of syconia were dehydrated in an ethanol series, fixed in Leica histological resin (Gerrits \& Horobin, 1991) and longitudinally sectioned (5 $\mu \mathrm{m}) \mathrm{using}$ a Leica RM 2245 rotary microtome. The sections were stained with $0.05 \%$ toluidine blue in phosphate buffer ( $\mathrm{pH}$ 6.3) (O'Brien, Feder \& McCully, 1964), and the slides were mounted at the time of observation with distilled water and a glass coverslip. Observations and photographs were taken with a Leica DFC 320 digital camera coupled with a Leica DM 4500 B light microscope. 
The emission and growth of pollen tubes in the stigma of a flower and between flowers were observed in fresh or fixed materials under LM. Pistils were softened and cleared in $20 \%$ sodium hydroxide at $60{ }^{\circ} \mathrm{C}$ for $20-40 \mathrm{~min}$, washed in distilled water, crushed in $0.1 \%$ aniline blue in $0.1 \mathrm{M}$ of $\mathrm{K}_{3} \mathrm{PO}_{4}$ buffer (Martin, 1959), mounted between slide and coverslip and observed under a Leica DM 5000 B epifluorescence light microscope with filter A (360-470 nm).

The ultrastructure of the growing pollen tube was studied using transmission electron microscopy (TEM). Samples of stigmas were fixed in Karnovsky's solution in 0.075 M phosphate buffer (pH 7.27.4) for $24 \mathrm{~h}$, washed in 0.075 M phosphate buffer (pH 7.2-7.4) (Karnovsky, 1965), post-fixed in 1\% osmium tetroxide in $0.075 \mathrm{M}$ phosphate buffer $(\mathrm{pH}$ 7.2-7.4) for $1 \mathrm{~h}$, gradually dehydrated in acetone solution and embedded in Araldite 6005. Subsequently, semi-thin sections $(0.5 \mu \mathrm{m})$ were obtained using a Leica Reichert ultramicrotome and stained with $0.05 \%$ toluidine blue (O'Brien et al., 1964). Ultrathin sections $(60 \mathrm{~nm})$ were obtained using a Leica Reichert ultramicrotome, stained with $2 \%$ uranyl acetate solution for $15 \mathrm{~min}$ (Watson, 1958) and lead citrate for $15 \mathrm{~min}$ (Reynolds, 1963), observed and documented using a Philips EM 208 transmission electron microscope.

The degree of cohesion between the stigmas followed a manual criterion of separation of the stigmas: loose, indicating that the stigmas were just touching each other with no effort required to separate them; and firm, for those that required some effort to separate them. The stigmatic papillae were characterized as short when they were the same height as the epidermal cells of the style, and long when they were at least twice the height of these cells.

\section{Results}

\section{The syconium and its flowers}

The studied Ficus spp. have syconia of different shapes and sizes (Table 2). All contain developing staminate flowers (Fig. 1A), short-styled pistillate flowers and longstyled pistillate flowers (Fig. 1B, C). The shorter-styled pistillate flowers are interspersed with longer-styled pistillate flowers (Fig. 1C), with all stigmas converging at the same level in the inner side of the syconium (Fig. 1C, D). The pistillate flowers have a unilocular ovary with one ovule, a style positioned laterally to the ovary and a stigmatic surface formed by one or two filiform branches partially covered by papillae (Fig. 1E, F).

\section{Stigma and synstigma}

In all species, the disposition of stigmas varied from a solitary stigma to groups of contiguous stigmas (synstigmas) histologically connected or not to each other, with variation in (1) the number of stigmas 
forming each synstigma, (2) the proximity between the synstigmas and (3) the degree of cohesion between the stigmas of a synstigma (Table 2, Figs 2 and 3).

The number of stigmas per cluster ranged from two to 20 in F. citrifolia Mill., F. eximia Schott, $F$. obtusifolia Kunth and F. roraimensis C.C.Berg and from two to ten in F. carautana J.Neves \& Emygdio and $F$. pertusa L.f. (Table 2). The number of flowers composing a synstigma does not depend on the number of flowers existing in the syconium, as exemplified in F. obtusifolia (Table 2). A qualitative analysis indicates that stigmas are in closer proximity in $F$. eximia, resulting in a more congested distribution in the syconium compared to the other species (cf. Fig. 2E with Figs 2A, C, 3A, C, E; Table 2).

The contact between the stigmas occurs through the intertwining of branches and papillae in all species (Table 2; Figs 2B, D, F, 3B, D, F). This intertwining may be firm or loose, regardless of the size of the papillae (see Table 2). In F. carautana, stigmatic papillae are short (Fig. 2B), and the degree of cohesion between stigmas is loose. In the other species in which contact is also loose, stigmatic papillae are long (Figs 2D, F, 3B, D, F; Table 2).

Pollen and pollen tube

The species exhibited little variation in pollen and pollen tube morphology and in the behaviour of the growing pollen tubes in the pistil. In each species, these characteristics did not vary between longerand shorter-styled flowers and even in previously oviposited flowers.

The pollen grain deposited on the stigmas is small, $c .8-10 \mu \mathrm{m}$. It germinates rapidly on the stigmatic papillae in almost all species at the first subphase (presence of living wasp) (Fig. 4A-C, E). Except for $F$. pertusa, the germination is slightly slower and was only observed at the second subphase (presence of dead wasp). The pollen tube grows through the exudate produced as a result of the degeneration of stigmatic cells, reaching the style at the third subphase (presence of dead wasp and decaying brownish stigmas) (Fig. 4D, E). It continues to grow through the intercellular spaces of the transmitting tissue (Fig. 4D, E) that occupies the central portion of the style until it reaches the ovary (Fig. 4F).

In five of the six species ( $F$. carautana, F. eximia, F. obtusifolia, F. pertusa and $F$. roraimensis) pollen tubes were observed growing from one stigma towards the adjacent stigma (Fig. 5). The pollen tubes in these cases did not grow straight, instead exhibiting small curvatures (Fig. 5D, E). Pollen tubes were observed in the style of oviposited and non-oviposited flowers. 
The pollen tube grows through intercellular spaces of the style without degradation of the transmitting tissue cells (Fig. 6). The cells of the transmitting tissue at the time of passage of the pollen tube are intact, with secretory activity, thin walls (Fig. 6), large vacuole (Fig. 6), central lobed nucleus (Fig. 6C) and peripheral cytoplasm, containing amyloplasts (Fig. 6A, C), rough endoplasmic reticulum (Fig. 6B, D), mitochondria (Fig. 6A, D) and numerous vesicles (Fig. 6A, C). The pollen tube has a dense cytoplasm (Fig. 6), is thick-walled, structured in an external stratum (probably pecto-cellulosic) and an internal stratum (probably callosic) (Fig. 6D). No cytoplasmic connections were observed between the pollen tube and adjacent cells of the transmitting tissue, but the walls of both appear to be closely linked (Fig. 6).

\section{Discussion}

The synstigma turns the fig into a large flower with an extragynoecial compitum

The fig inflorescence containing many small uniovulate flowers could be functionally compared to a large flower with an apocarpous gynoecium. However, this configuration does not present the inherent disadvantage of apocarpy in terms of pollination efficiency. Indeed, the synstigma acts as (Endress, 1982; Endress, Jenny \& Fallen, 1983). a common surface for pollen germination, growth The compitum is a region of the pistil where the and competition of pollen tubes, analogous to the pollen tubes converge (Endress, 2011), allowing the function of a compitum in syncarpous gynoecium distribution of pollen tubes between carpels (Carr \& Carr, 1961) and acting as a site of pollen tube selection (Endress, 1982; Erbar, 2003; Lora, Hormaza \& Herrero, 2016). Thus, the synstigma of Ficus is functionally analogous to a special type of compitum, the extragynoecial found in some groups, formed in the external surfaces of the gynoecia (Endress, 1979, 1982; Endress \& Lorence, 1983; Endress et al., 1983; Endress \& Igersheim, 2000; Vieira \& Shepherd, 2002; Lyew et al., 2007; Du \& Wang, 2012; Lau et al., 2017).

A common type of extragynoecial compitum involves abundant mucilage secreted by the stigmatic papillae, as commonly found in some groups of earlydiverging angiosperms (Endress, 1979, 2011; Endress \& Lorence, 1983; Endress \& Igersheim, 2000; Wang, Armbruster \& Huang, 2012; Endress \& Doyle, 2015; Lau et al., 2017). The mucilage serves as a germination medium and aids in the selection and distribution in Monimiaceae (Endress, 1979, 1982). However, as of pollen tubes between the carpels. An extreme the synstigma of Ficus does not produce abundant case of this condition is the 'hyperstigma' described secretion (Heslop-Harrison \& Shivanna, 1977; Ramírez-Benavides, 2007; present study), synstigma cohesion is mainly the result of the physical intertwining of the stigmatic 
branches and papillae (Teixeira et al., 2018). As such, the synstigma is functionally analogous to single flowers with carpels post-genitally and distally united, as found in Malvaceae, Apocynaceae and Sapindales (Endress et al., 1983; Vieira \& Shepherd, 2002).

\section{Competition among flowers within a syconium causes changes in pollen tube morphology}

We detected no differences between floral morphs in characteristics related to pollen grain germination and pollen tube growth, suggesting that the plant has no mechanism to favour preferential fertilization of long-styled pistillate flowers. Similarly, we did not find any variation in the behaviour and morphology of the pollen tubes between Ficus spp. having different numbers of flowers per syconium and different degrees of cohesion of the synstigma. A looser synstigma or a synstigma formed of few stigmas could be predicted to favour the formation of branched pollen tubes in an attempt to broaden the resources for tube growth (Maheshwari, 1950). Branched pollen tubes were found in F. citrifolia, a species with loose synstigmas, but as no pollen tubes were observed growing between flowers, it was not possible to check the presence of this condition. In F. carautana, F. obtusifolia and F. roraimensis, pollen germination was rapid (at the first subphase, when living wasps are present), as observed in the species presenting a firm synstigma and similar to that observed in the passively pollinated $F$. carica, which does not form synstigmas and in which pollen tubes were observed on the style $24 \mathrm{~h}$ after pollination (Beck \& Lord, 1988).

The rapid pollen germination in the studied Ficus spp. probably results from the release of tricellular pollen grains from the anthers (documented in F. elastica Roxb. ex Hornem.; Zhang, Liu \& Sodmergen, 2003), resulting in short-lived pollen (Dafni \& Firmage, 2000). Our results suggest that the pollen tube in Ficus is heterotrophic during its growth, depending on external resources provided by the exudates released by the stigmatic cells and the transmitting tissue. This idea is supported by the observation that pollen tubes in Ficus grow through intercellular spaces and not by penetration/degradation of transmitting tissue cells. Indeed, heterotrophic pollen tube growth through intercellular spaces has been reported for many other taxa (Maheshwari, 1950; Mulcahy \& Mulcahy, 1982; Taylor \& Hepler, 1997; Graaf, Derksen \& Mariani, 2001; Lersten, 2004; Malhó, 2006).

The curvilinear morphology of the pollen tubes growing laterally in the synstigma has also been observed in F. fulva (fig. 2b in Jousselin \& Kjellberg, 2001). We suggest that stigmas composing the synstigma compete for pollen tubes, by producing chemotrophic signals. These signals would indicate which stigmas have not yet been contacted by pollen and, thus, would be more attractive to germination. The stigmatic papillae, after the deposition and germination of the pollen grain, undergo 
physical and chemical changes that alter their receptivity and the consequent ability to attract and sustain the growth of pollen tubes (Adhikari et al., 2020), interfering with their direction. Other two alternative explanations seem less plausible. (1) The connection between the stigmas could expose the pollen tube to the independent, simultaneous chemical signals emitted by the egg cells (Herrero, 2000; Okuda \& Higashiyama, 2010) from the female gametophyte of the flower in which the pollen was deposited and by the egg cells present in surrounding flowers, united by the synstigma. These conflicting signals might change the direction of the pollen tube growth, resulting in numerous short bends along the pollen tube that meanders over the synstigma. However, although important in the guidance of the growing pollen tube, the signals from the female gametophyte cells are restricted to the ovarian and ovule tissues. The beginning of the pollen tube trajectory, through the stigma and style, is mediated by signals from the sporophyte (Zheng et al., 2018). (2) Incompatibility mechanisms among flowers located near the pollinated flower might generate the atypical pollen tube morphology (see Lee, 1984). This is also unlikely, because the production of viable seeds in neighbouring flowers and the occurrence of natural and manipulative hybridization (Condit, 1950; Parrish et al., 2003) indicate that incompatibility mechanisms are absent in Ficus.

The synstigma of Ficus section Americanae does not form a continuous surface as observed in Ficus section Sycocarpus Miq. (fig. 2a in Jousselin \& Kjellberg, 2001). Instead, figs of the studied species had several synstigmas formed by groups of two to 20 flowers. The selective pressures for variation in the number of flowers that compose each synstigma are obscure. We tried to explore one potential reason for variation by investigating species in which syconia covered a large range in size, reflected by their number of flowers, but we did not find any obvious connection. Natural history data related with pollination behaviour could provide insight into this question, as pollen availability seems to be a limiting factor in Ficus (Kjellberg et al., 2014, Wang et al., 2014). Also, the wasp pollination behaviour largely affects the pollen distribution inside the syconium, because in the active pollination pollen grains are deposited in batches on some stigmas.

\section{Outlook}

The presence of pollen tubes growing from one stigma to another in $F$. carautana, $F$. eximia, $F$. obtusifolia, F. pertusa and F. roraimensis supports the hypothesis that synstigmas act as distributors of pollen tubes to flowers situated near those that have been pollinated, thus modifying the pattern of fertilization and promoting wasp offspring without seed predation or, at least, reducing seed predation. In this way, we expand the preliminary information about distribution of pollen tubes by synstigmas 
in F. fulva Reinw., F. condensa King (Jousselin \& Kjellberg, 2001), F. microcarpa L.f., F. salicifolia Vahl and F. sur Forssk. (Jousselin et al., 2003a). Pollen tubes were also observed in the style of oviposited flowers, confirming that pollinating wasp larvae found in the syconium of monoecious Ficus spp. with active pollination may develop at the expense of the plant embryo and endosperm and may therefore be affected by embryo sac fertilization (Jansen-González, Teixeira \& Pereira, 2012). Precise observations of wasp behaviour are now needed to better understand the roles of the stigmatic structure for pollen deposition behaviour, actual locus and pattern of pollen deposition.

\section{Acknowledgements}

We thank Edimárcio da Silva Campos (FCFRP/USP), Maria Dolores S. Ferreira (Tuca), José A. Maulin and Maria Teresa P. Maglia (FMRP/USP) for technical assistance and Camila D. Souza and Luciano Palmieri (University of São Paulo, Ribeirão Preto, Brazil) for the Ficus samples, Dewey Litwiller (Language Centre at the University of Saskatchewan) for the English revision and Dr Louis Ronse De Craene and an anonymous reviewer for the critical reading of the manuscript. This work was supported by FAPESP (grant numbers 2012/02374-2 and 2014/07453-3), FAPERJ (grant numbers E-26/202.411/2017 and E-26/202.412/2017), CNPq (grant numbers 305793/2018-7, 303493/2015-1 and 302806/2019-9) and CAPES (code 001).

\section{References}

Adhikari PB, Liu X, Wu X, Zhu S, Kasahara RD. 2020. Fertilization in flowering plants: an odyssey of sperm cell delivery. Plant Molecular Biology 103: 9-32.

Al-Beidh S, Dunn DW, Power SA, Cook JM. 2012. Parasites and mutualism function: measuring enemy-free space in a fig-pollinator symbiosis. Oikos 121: 1833-1839.

Anstett MC. 2001. Unbeatable strategy, constraint and coevolution, or how to resolve evolutionary conflicts: the case of the fig/wasp mutualism. Oikos 95: 476-484.

Basso-Alves JP, Pereira RAS, Peng YQ, Teixeira SP. 2014. Different ontogenetic processes promote dicliny in Ficus L. (Moraceae). Acta Oecologica 57: 5-16.

Beck NG, Lord EM. 1988. Breeding system in Ficus carica, the common fig. II. pollination events. American Journal of Botany 75: 1913-1922.

Berg CC. 2005. Moraceae diversity in a global perspective. Biologiske Skrifter 55: 423-440.

Bruun-Lund S, Verstraete B, Kjellberg F, Rønsted N. 2018. Rush hour at the museumdiversification patterns provide new clues for the success of figs (Ficus L., Moraceae). Acta Oecologica 90: 4-11.

Carr SGM, Carr DJ. 1961. The functional significance of syncarpy. Phytomorphology 11: 249-256. 
Carvalho JDT, Mariath JEA. 2019. Synflorescence morphology of species of Typha L. (Typhaceae): anatomical and ontogenetic bases for taxonomic applications. Acta Botanica Brasilica 33: 672682.

Clement WL, Bruun-Lund S, Cohen A, Kjellberg F, Weiblen GD, Rønsted N. 2020. Evolution and classification of figs (Ficus, Moraceae) and their close relatives (Castilleae) united by involucral bracts. Botanical Journal of the Linnean Society 193: 316-339. Condit IJ. 1950. An interspecific hybrid of Ficus. Journal of Heredity 41: 165-168.

Dafni A, Firmage D. 2000. Pollen viability and longevity: practical, ecological and evolutionary implications. Plant Systematics and Evolution 222: 113-132.

$\mathrm{Du} \mathrm{W}$, Wang XF. 2012. Intercarpellary growth of pollen tubes in the extragynoecial compitum and its contribution to fruit set in an apocarpous species, Schisandra sphenanthera (Schisandraceae). American Journal of Botany 99: 961-966.

Endress PK. 1979. Noncarpellary pollination and 'hyperstigma' in an angiosperm (Tambourissa religiosa, Monimiaceae). Experientia 35: 45.

Endress PK. 1982. Syncarpy and alternative modes of escaping disadvantages of apocarpy in primitive angiosperms. Taxon 31: 48-52.

Endress PK. 2011. Evolutionary diversification of the flowers in angiosperms. American Journal of Botany 98: 370-396.

Endress PK, Doyle JA. 2015. Ancestral traits and specializations in the flowers of the basal grade of living angiosperms. Taxon 64: 1093-1116.

Endress PK, Igersheim A. 2000. Gynoecium structure and evolution in basal angiosperms. International Journal of Plant Sciences 161: S211-S213.

Endress PK, Jenny M, Fallen ME. 1983. Convergent elaboration of apocarpous gynoecia in higher advanced dicotyledons (Sapindales, Malvales, Gentianales). Nordic Journal of Botany 3: 293-300.

Endress PK, Lorence DH. 1983. Diversity and evolutionary trends in the floral structure of Tambourissa (Monimiaceae). Plant Systematics and Evolution 143: 53-81.

Erbar C. 2003. Pollen tube transmitting tissue: place of competition of male gametophytes. International Journal of Plant Sciences 164: S265-S277.

Galil J, Eisikowitch D. 1968. On the pollination ecology of Ficus sycomorus in East Africa. Ecology 49: 259-269.

Gerrits PO, Horobin RW. 1991. The application of glycol methacrylate in histotechnology; some fundamental principles. Groningen: Faculteit der Geneeskunde, Rijksuniversiteit Groningen.

Graaf BHJ, Derksen JWM, Mariani C. 2001. Pollen and pistil in the progamic phase. Sexual Plant Reproduction 14: 41-55.

Herrero M. 2000. Changes in the ovary related to pollen tube guidance. Annals of Botany 85: S79S85.

Heslop-Harrison Y, Shivanna KR. 1977. The receptive surface of the angiosperm stigma. Annals of Botany 41: 1233-1258.

Jansen-González S, Teixeira SP, Pereira RAS. 2012. Mutualism from the inside: coordinated development of plant and insect in an active pollinating fig wasp. ArthropodPlant Interactions 6: 601-609.

Johansen DA. 1940. Plant microtechnique. New York: McGraw-Hill.

Jousselin E, Hossaert-McKey M, Herre EA, Kjellberg F. 2003a. Why do fig wasps actively pollinate monoecious figs? Oecologia 134: 381-387. 
Jousselin E, Kjellberg F. 2001. The functional implications of active and passive pollination in dioecious figs. Ecology Letters 4: 151-158.

Jousselin E, Kjellberg F, Herre EA. 2004. Flower specialization in a passively pollinated monoecious fig: a question of style and stigma? International Journal of Plant Sciences 165: 587-593.

Jousselin E, Rasplus JY, Kjellberg F. 2003b. Convergence and coevolution in a mutualism: evidence from a molecular phylogeny of Ficus. Evolution 57: 1255-1269.

Karnovsky MJ. 1965. A formaldehyde-glutaraldehyde fixative of high osmolality for use in electron microscopy. Journal of Cell Biology 27: 137A-138A.

Kemp JR, Kevan PG, Posluszny U. 1993. Morphological differences and changes of the gynoecium in short-lived flowers of Rosa setigera Michaux and their relationship to dioecy. International Journal of Plant Sciences 154: 550-556.

Kjellberg F, Jousselin E, Hossaert-McKey M, Rasplus JY.

2005. Biology, ecology and evolution of fig pollinating wasps (Chalcidoidea: Agaonidae). In: Raman A, Schaefer CW, Withers TM, eds. Biology, ecology and evolution of gall inducing arthropods. Plymouth: Science Publishers, 539-572. Kjellberg F, Suleman N, Raja S, Tayou A, HossaertMcKey M, Compton SG. 2014. Some pollinators are more equal than others: factors influencing pollen loads and seed set capacity of two actively and passively pollinating fig wasps. Acta Oecologica 57: 73-79.

Lau JYY, Pang CC, Ramsden L, Saunders RMK. 2017. Stigmatic exudate in the Annonaceae: pollinator reward, pollen germination medium or extragynoecial compitum? Journal of Integrative Plant Biology 59: 881-894.

Lee TD. 1984. Patterns of fruit maturation: a gametophytic competition hypothesis. American Naturalist 123: 427-432.

Lersten NR. 2004. Flowering plant embryology. Oxford: Blackwell Publishing Ltd.

Lillie RD. 1954. Histopathologic technic and practical histochemistry. New York: McGraw-Hill (Blakiston).

Lora J, Hormaza JI, Herrero M. 2016. The diversity of the pollen tube pathway in plants: toward an increasing control by the sporophyte. Frontiers in Plant Science 7: 107.

Lyew J, Li Z, Liang-Chen Y, Luo YB, Sage TL. 2007. Pollen tube growth in association with a drytype stigmatic transmitting tissue and extragynoecial compitum in the basal angiosperm Kadsura longipedunculata (Schisandraceae). American Journal of Botany 94: 1170-1182.

Maheshwari P. 1950. An introduction to the embryology of angiosperms. New York: McGraw-Hill.

Malhó R (ed.). 2006. The pollen tube. A cellular and molecular perspective. Plant Cell Monographs (3). Berlin/Heidelberg: Springer-Verlag.

Martin FW. 1959. Staining and observing pollen tubes in the style by means of fluorescence. Stain Technology 34: 125-128.

Mulcahy GB, Mulcahy DL. 1982. The two phases of growth of Petunia hybrida (Hort. Vilm-Andz.) pollen tubes through compatible styles. Journal of Palynology 18: 61-64.

Nicholls MS, Cook CDK. 1986. The function of pollen tetrads in Typha (Typhacae). Veröffentlichungen des Geobotanischen Institutes, Stiftung Rübel 87: 112-119.

O'Brien TP, Feder N, McCully ME. 1964. Polychromatic staining of plant cell walls by toluidine blue O. Protoplasma 59: 368-373.

Okuda S, Higashiyama T. 2010. Pollen tube guidance by attractant molecules: LUREs. Cell Structure \& Function 35: 45-52. 
Parrish TL, Koelewijn HP, van Dijk PJ, Kruijt M. 2003. Genetic evidence for natural hybridization between species of dioecious Ficus on island populations. Biotropica 35: 333-343.

Ramírez-Benavides W. 2007. Pollination analogies between Orchidaceae, Ficus (Moraceae) and Asclepiadaceae. Lankesteriana 7: 450-457.

Reynolds ES. 1963. The use of lead citrate at high $\mathrm{pH}$ as an electron-opaque stain in electron microscopy. The Journal of Cell Biology 17: 208-212.

Taylor LP, Hepler PK. 1997. Pollen germination and tube growth. Annual Review of Plant Physiology and Plant Molecular Biology 48: 461-491.

Teixeira SP, Costa MFB, Basso-Alves JP, Kjellberg F, Pereira RAS. 2018. Morphological diversity and function of the stigma in Ficus species (Moraceae). Acta Oecologica 90: 117-131.

Verkerke W. 1989. Structure and function of the fig. Experientia 45: 612-622.

Vieira MF, Shepherd GJ. 2002. Oxypetalum banksii subsp. banksii: a taxon of Asclepiadaceae with an extragynoecial compitum. Plant Systematics and Evolution 233: 199-206.

Wang XF, Armbruster WS, Huang SQ. 2012. Extragynoecial pollen-tube growth in apocarpous angiosperms is phylogenetically widespread and probably adaptive. New Phytologist 193: 253260.

Wang G, Chen J, Li ZB, Zhang FP, Yang DR. 2014. Has pollination mode shaped the evolution of Ficus pollen? PLoS One 9: e86231.

Watson ML. 1958. Staining of tissue sections for electron microscopy with heavy metals. The Journal of Cell Biology 4: 475-478.

Weberling F. 1989. Morphology of flowers and inflorescences. Cambridge: Cambridge University Press.

Zheng YY, Lin XJ, Liang HM, Wang FF, Chen LY. 2018. The long journey of pollen tube in the pistil. International Journal of Molecular Sciences 19: 3529.

Zhang Q, Liu Y, Sodmergen. 2003. Examination of the cytoplasmic DNA in male reproductive cells to determine the potential for cytoplasmic inheritance in 295 angiosperm apecies. Plant and Cell Physiology 44: 941-951. 
Table 1. Information about sampled species of Ficus section Americanae

\begin{tabular}{llll}
\hline Species & Collection site & Collection date & Voucher \\
\hline F. carautana L.J.Neves \& Emygdio & Corumbá, MS, Brazil & $03 / 2012$ & R.A.S.Pereira et al. 178 (SPFR) \\
F. citrifolia Mill. & Ribeirão Preto, SP, Brazil & $09 / 2011$ & S.P.Teixeira et al. 79 (SPFR) \\
F. eximia Schott & Ribeirão Preto, SP, Brazil & $04 / 2012$ & R.A.S.Pereira et al. 138 (SPFR) \\
F. obtusifolia Kunth & Galia, SP, Brazil & $10 / 2011$ & R.A.S.Pereira et al. 158 (SPFR) \\
F. pertusa L.f. & Ribeirão Preto, SP, Brazil & $07 / 2011$ & R.A.S.Pereira et al. 127 (SPFR) \\
F. roraimensis C.C.Berg & Manaus, AM, Brazil & $07 / 2012$ & Alcohol collection (FCFR/USP) \\
\hline
\end{tabular}


Table 2. Information on stigma / synstigma morphology in the studied species of Ficus sect. Americanae. Symbols: fec = short styled flower; fel = long styled flower.

\begin{tabular}{|c|c|c|c|c|c|c|c|c|}
\hline \multirow[b]{2}{*}{ Species } & \multirow{2}{*}{$\begin{array}{l}\text { Approximate } \\
\text { number of } \\
\text { flowers in a } \\
\text { syconium }\end{array}$} & \multicolumn{2}{|c|}{$\begin{array}{l}\text { Number of } \\
\text { branches per } \\
\text { stigma }\end{array}$} & \multicolumn{5}{|c|}{ Synstigma characteristics } \\
\hline & & fec & fel & Arrangement & $\begin{array}{l}\text { Flower } \\
\text { number }\end{array}$ & $\begin{array}{c}\text { Type of } \\
\text { intertwining }\end{array}$ & $\begin{array}{l}\text { Size of } \\
\text { stigmatic } \\
\text { papillae }\end{array}$ & $\begin{array}{l}\text { Degree of } \\
\text { cohesion } \\
\text { between } \\
\text { stigmata }\end{array}$ \\
\hline F. carautana & 258 & $1-2$ & $1-2$ & spaced & $2-10$ & branches/papillae & short & loose \\
\hline F. citrifolia & 494 & $1-2$ & $1-2$ & spaced & $2-17$ & branches/papillae & long & loose \\
\hline F. eximia & 532 & $1-2$ & $1-2$ & congested & $2-20$ & branches/papillae & long & firm \\
\hline F. obtusifolia & 1738 & 2 & $1-2$ & spaced & $2-15$ & branches/papillae & long & loose \\
\hline F. pertusa & 210 & $1-2$ & $1-2$ & congested & $2-11$ & branches/papillae & long & firm \\
\hline F. roraimensis & 440 & $1-2$ & $1-2$ & spaced & $2-20$ & branches/papillae & long & loose \\
\hline
\end{tabular}




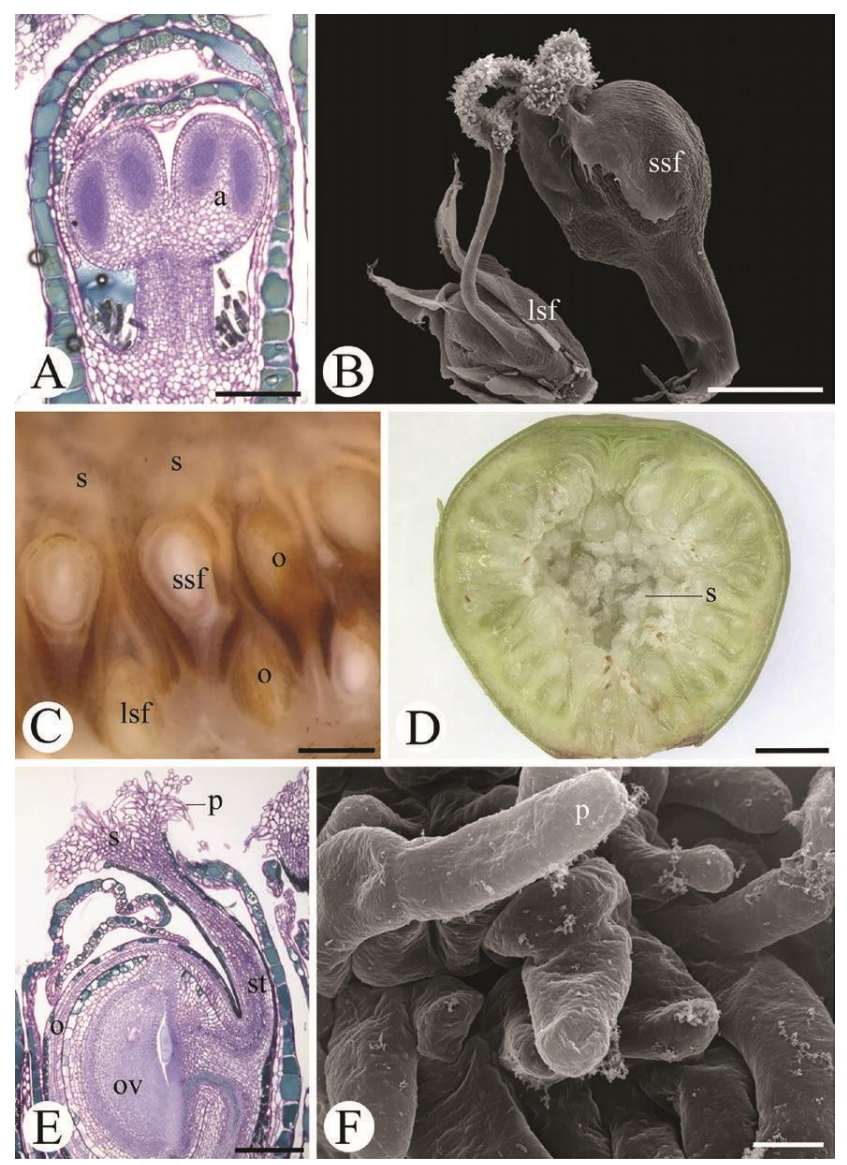

Figure 1. Morphological aspects of the flowers of Ficus citrifolia (A, C, D), F. obtusifolia (B) and F. pertusa (E). A, Longitudinal section of a staminate flower highlighting the young developing anthers. B, Surface view of a short-styled pistillate flower and a long-styled pistillate flower. C, Interspersed arrangement of short-styled and long-styled pistillate flowers within a syconium showing the ovaries at different levels and stigmas at the same level. D, Overview of half a syconium cut longitudinally showing the pistillate flowers with stigmas at the same level. E, Longitudinal section of a pistillate flower showing the anacrostylous ovary with one locule and one ovule and papillate stigma. F, Detail of stigmatic papillae. Symbols: $\mathrm{a}=$ anther, lsf = long-styled flower, o = ovary, ov = ovule, $\mathrm{p}=$ papilla, $\mathrm{s}=$ stigma, $\mathrm{ssf}=$ short-styled flower, $\mathrm{st}=$ style. Scale bars: $\mathrm{A}, \mathrm{E}=20 \mu \mathrm{m} ; \mathrm{B}, \mathrm{C}=500 \mu \mathrm{m} ; \mathrm{D}=2 \mathrm{~mm}$; $\mathrm{F}=100 \mu \mathrm{m}$. 

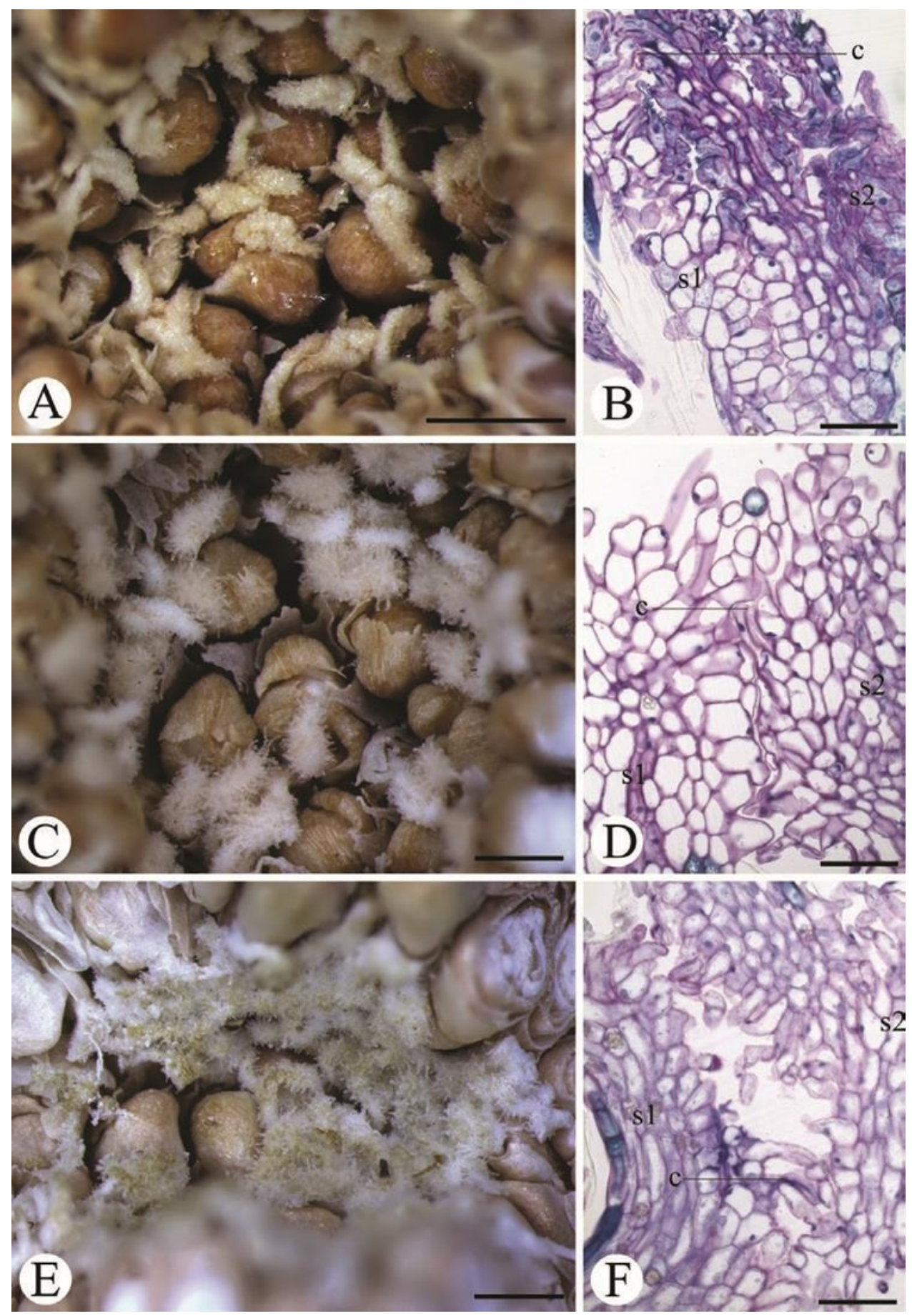

Figure 2. Arrangement within a syconium and anatomy of the synstigma of Ficus carautana (A, B), $F$. citrifolia $(\mathrm{C}, \mathrm{D})$ and $F$. eximia $(\mathrm{E}, \mathrm{F})$. There is a variation in the proximity between synstigmas featuring a more spaced $(\mathrm{A}, \mathrm{C})$ or more congested $(\mathrm{E})$ distribution. Note a connecting region between the papillae of two stigmas (B, D, F). Symbols: $c=$ connecting region, s1, s2 = stigma 1 and 2. Scale bars: $\mathrm{A}, \mathrm{C}, \mathrm{E}=500 \mu \mathrm{m} ; \mathrm{B}, \mathrm{D}, \mathrm{F}=50 \mu \mathrm{m}$. 

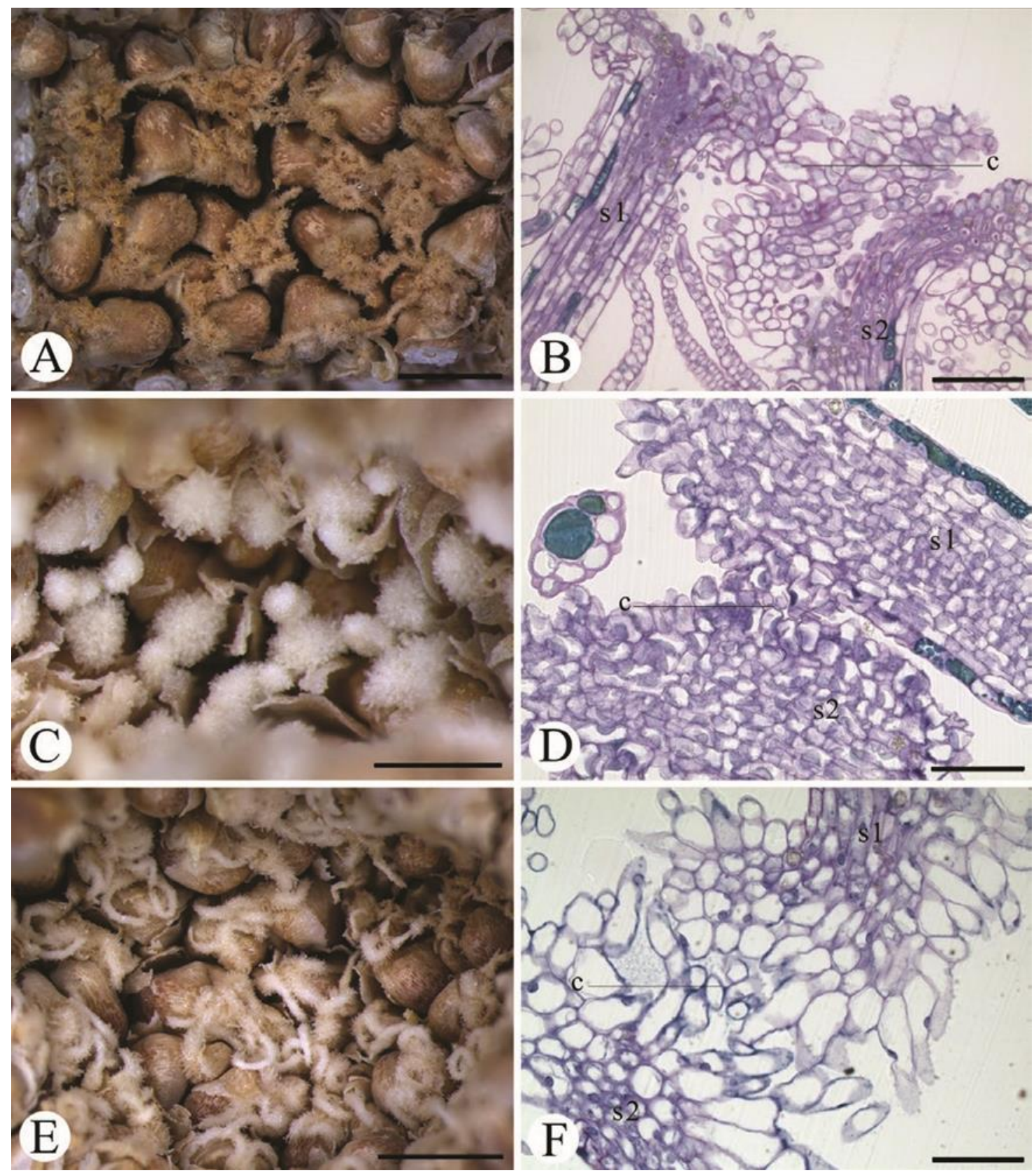

Figure 3. Arrangement within a syconium and anatomy of the synstigma of Ficus obtusifolia (A, B),

$F$. pertusa $(\mathrm{C}, \mathrm{D})$ and $F$. roraimensis $(\mathrm{E}, \mathrm{F})$. There is a variation in the proximity between synstigmas featuring a more spaced distribution (A, C, E). Note a connecting region between the papillae of two stigmas (B, D, F). Symbols: c = connecting region, s1, s2 = stigma 1 and 2. Scale bars: A, C, E = 500 $\mu \mathrm{m} ; \mathrm{B}, \mathrm{D}, \mathrm{F}=50 \mu \mathrm{m}$. 

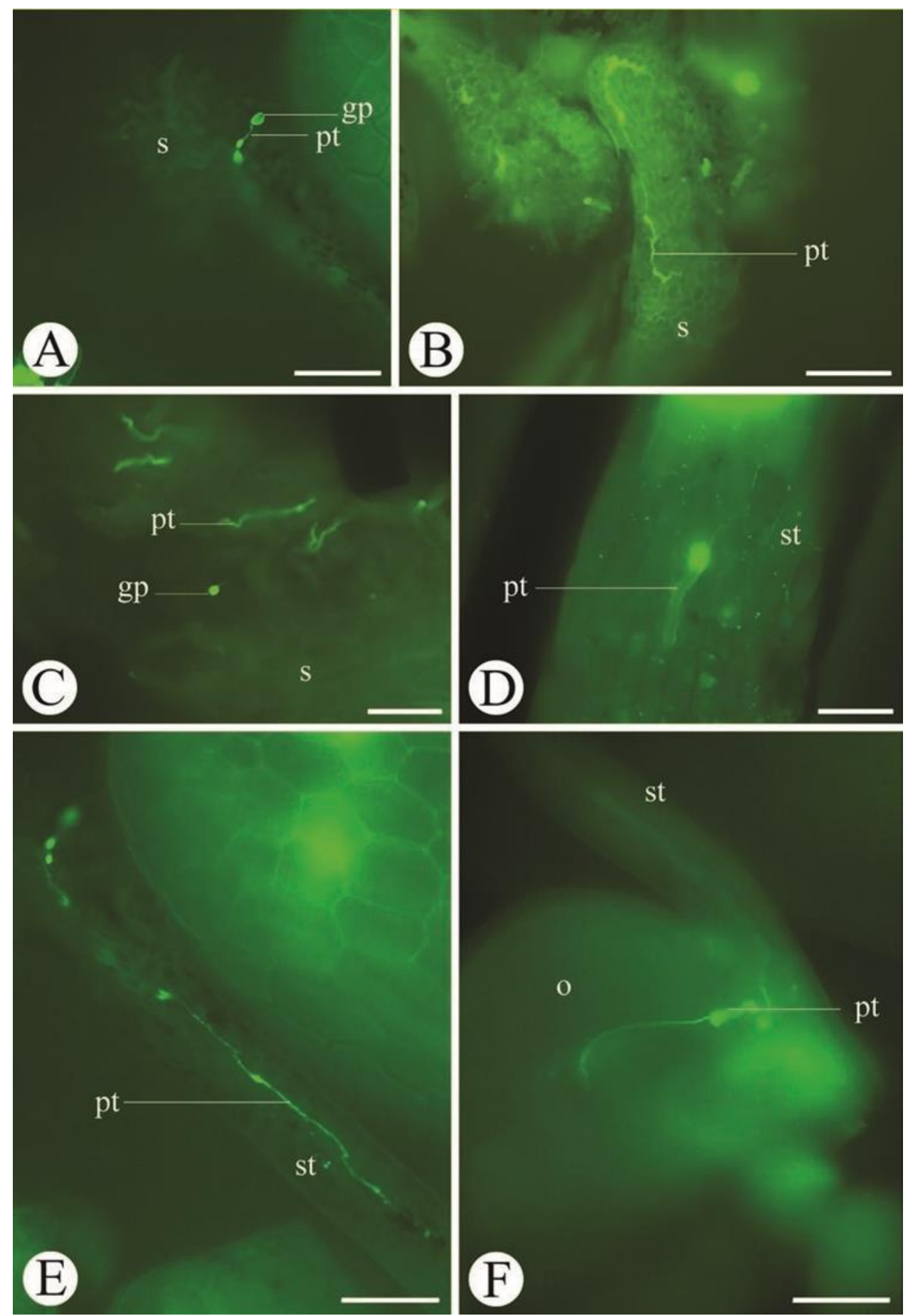

Figure 4. Epifluorescent images of the pollen tube growth through the stigma, style and ovary of Ficus citrifolia $(\mathrm{A}, \mathrm{D}, \mathrm{F})$, F. eximia $(\mathrm{B})$, F. roraimensis $(\mathrm{C})$ and $F$. carautana $(\mathrm{E})$. A-C. Pollen grains on the stigma and pollen tubes growing through stigmatic papillae. D, E, Pollen tubes on the style traversing the transmitting tissue. F, Pollen tube reaching the ovary. Symbols: gp = germinating pollen grain, $o$ $=$ ovary, $\mathrm{pt}=$ pollen tube, $\mathrm{s}=$ stigma, st $=$ style. Scale bars: $\mathrm{A}, \mathrm{B}=100 \mu \mathrm{m} ; \mathrm{C}=50 \mu \mathrm{m} ; \mathrm{D}, \mathrm{F}=200$ $\mu \mathrm{m} ; \mathrm{E}=20 \mu \mathrm{m}$. 

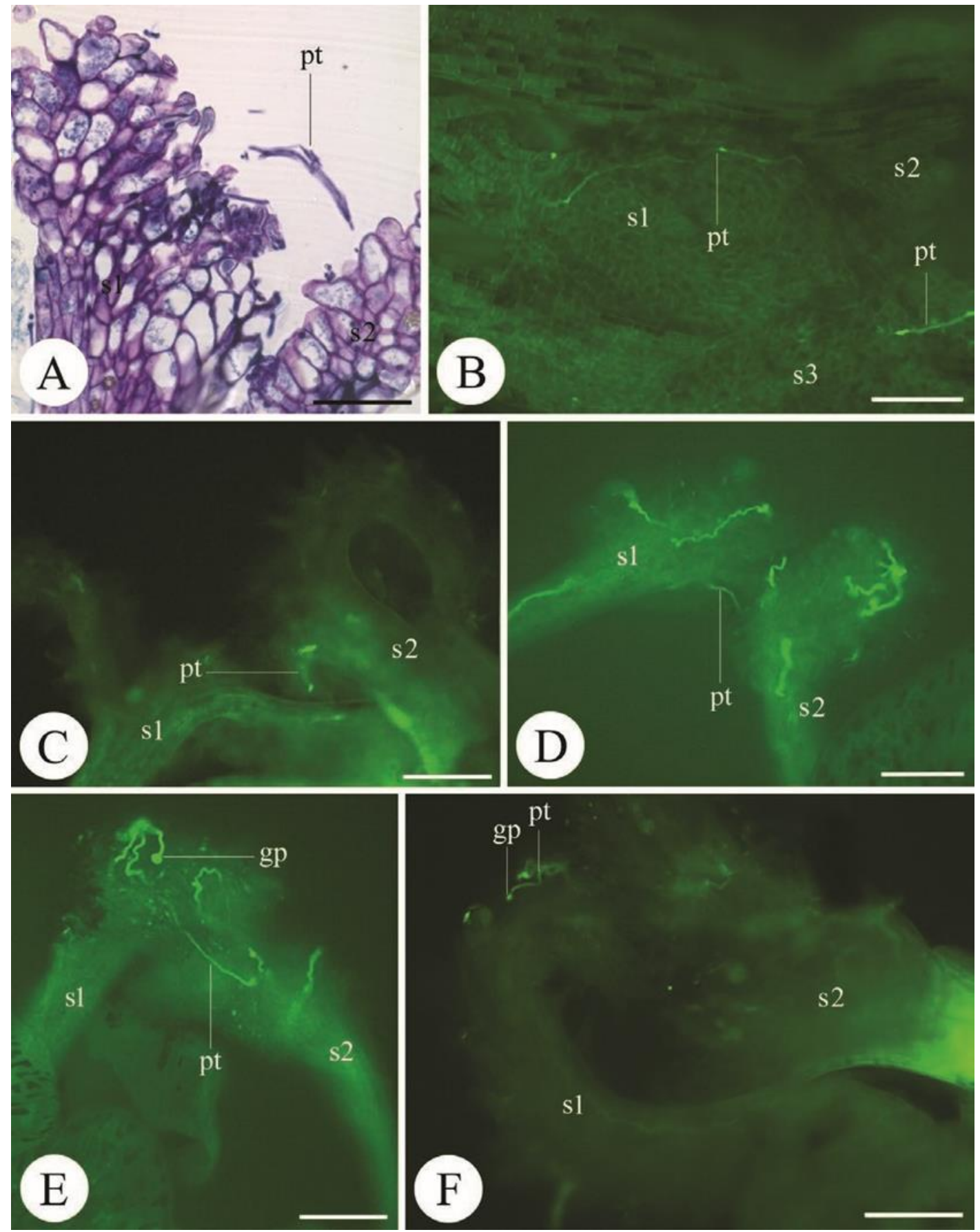

Figure 5. Stigma views (LM) of Ficus carautana (A), F. eximia (B), F. obtusifolia (C), F. pertusa (D, E) and $F$. roraimensis $(\mathrm{F})$. Pollen tube growing from one stigma towards the adjacent one. Note the pollen grains germinating on the stigma (E, F). Symbols: s1, s2, s3 = stigma 1, 2 and 3, st = style, gp $=$ germinating pollen grain, $\mathrm{pt}=$ pollen tube. Scale bars: $\mathrm{A}=50 \mu \mathrm{m} ; \mathrm{B}, \mathrm{C}, \mathrm{E}, \mathrm{F}=100 \mu \mathrm{m} ; \mathrm{D}=20 \mu \mathrm{m}$. 


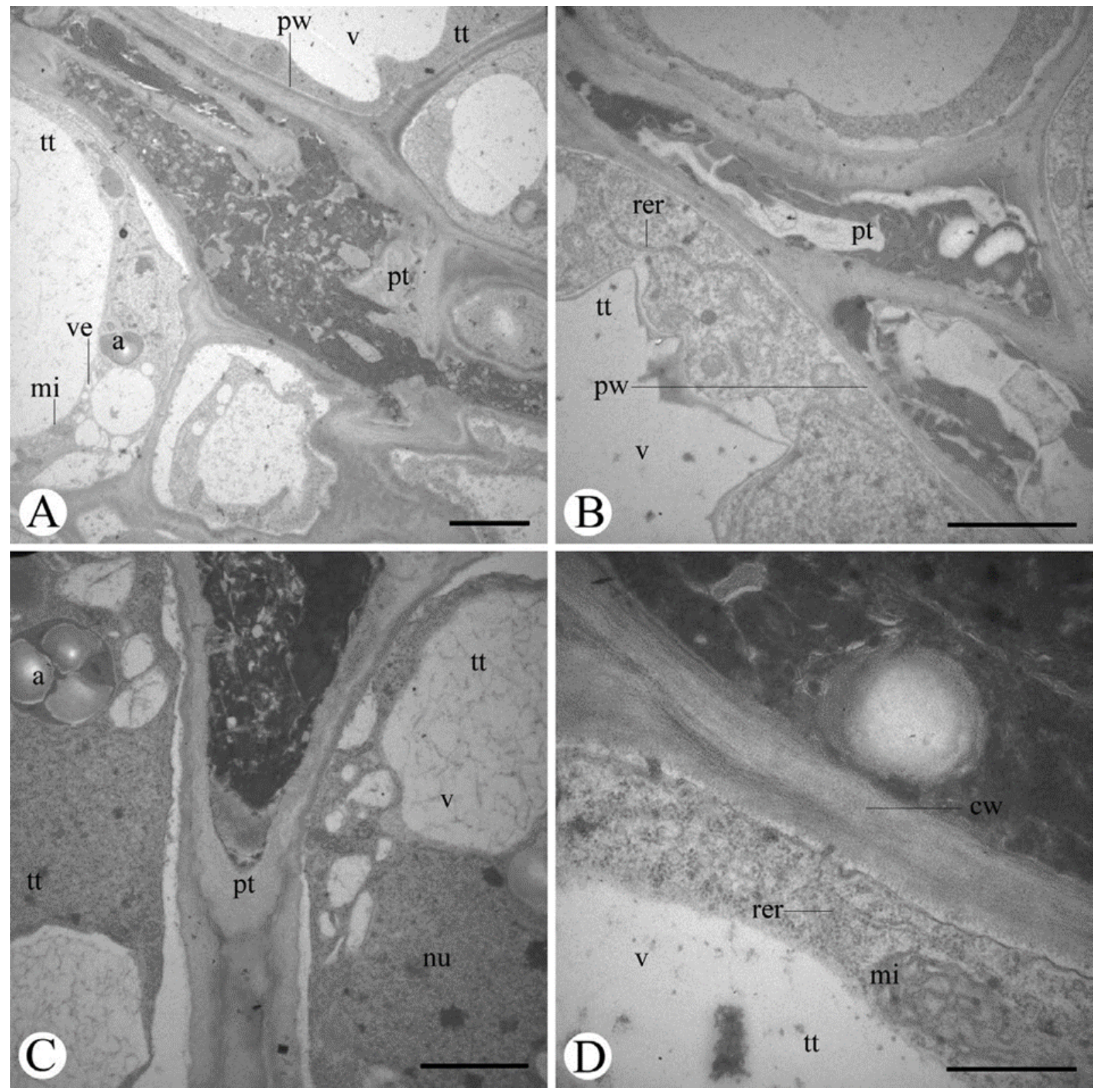

Figure 6. Ultrastructure (TEM) of the pollen tube growing through the style of flowers of Ficus citrifolia (A, D), F. obtusifolia (B) and F. pertusa (C). A, B, Pollen tube surrounded by intact cells of the transmitting tissue. Note the electron-dense content of the pollen tube. $C$, Detail of two cells of the transmitting tissue showing thin walls, large vacuoles, amyloplasts, central lobed nucleus. Note the tip of a pollen tube located between the walls of the two transmitting tissue cells. D, Detail of the pollen tube showing the thick wall, the innermost stratum consisting of translucent substance (callose). Note a transmitting tissue cell with a large vacuole, mitochondria and an extensive rough endoplasmic reticulum. Symbols: $\mathrm{a}=$ amyloplast, $\mathrm{cw}=$ callosic wall, $\mathrm{mi}=$ mitochondria, $\mathrm{nu}=$ nucleus, $\mathrm{pt}=\mathrm{pollen}$ tube, $\mathrm{pw}=$ pollen tube wall, $\mathrm{rer}=$ rough endoplasmic reticulum, $\mathrm{tt}=$ transmitting tissue, $\mathrm{v}=$ vacuole, ve $=$ vesicle. Scale bars: $\mathrm{A}=5 \mu \mathrm{m} ; \mathrm{B}, \mathrm{C}=3 \mu \mathrm{m} ; \mathrm{D}=1 \mu \mathrm{m}$. 